\title{
The Economic Basis of Stupidity
}

\author{
James F Welles* \\ East Marion, New York, USA \\ *Corresponding author: James F Welles, PhD, P.O. Box 17, East Marion, New York, USA
}

Submission: 傮 February 22, 2018; Published: 眥 February 26, 2018

\section{Opinion}

One of the basic problems with which all leaders must contend is that the ideals and ideas they are expected to use to solve existing problems are often simply common assumptions. This is particularly true in the field of economics-a domain in which beliefs and arguments over them have in the past century clearly become religious in nature. The general field of economics relates to the system of allocating productive goods and the land, tools and labour employed to produce them. The need for systems is a cultural universal [1], but one might legitimately inquire as to just how systematic the systems are. Capitalism really is not a system: it is economic anarchy. Socialism is too systematic: it stifles initiative with plans for state traction. Communism ${ }^{1}$ is economic democracycollective stupidity, with each detracting according to his means and by 1842 using a universal language based on "Hunger", "Envy" and "Death" [2]. Fascism is economic over think.

Pure economic systems are not to be found except in the minds and tomes of economic theorists. In the real world, people need some way to organize their resources, equipment and labour so that goods can be produced and distributed [3]. The actual system used by a given society is an expression of its cultural ideology and is sanctioned by an economic schema which defines "Right and wrong" in quasi religious terms. The discrepancies between the ideal and real systems are due to the compromises people must make to function, however ineffectively, in a world of physical limitations, egos, selfishness and ineptitude. In fact, the theoretical systems might better be considered distractions which keep people from understanding what they are doing.

As unsystematic systems, economic disorganizations have ideological explanations which are neither reasonable nor accurate. Indeed, what devotees thereof have created for themselves is what they need-emotionally satisfying religious sanctifications. For example, Calvin Coolidge apparently thought the business of America was something holier than just business. He referred to the capitalist's factory in pre-Crash America as a "Temple", opined "The man who works there worships there" [4] and declared that "Advertising ministers to the spiritual side of trade" [5]. Indeed, words like trust, faith and belief, borrowed from religious institutions by capitalists, do make business seem sacred [6]. It is hardly surprising that stupidity plays a large role in economic life [7] when leaders who not only accept but even revere the establishment with religious fervour have their critical thinking shaped into wilful ignorance and blindness by their devout beliefs. In fact, Voltaire considered the London Stock Exchange (i.e. the Stock Market) as a secular embodiment of psychic harmony where Jews, Muslims and Christians can engage in their unifying faith-Mammonism-and apply the term "Infidel" only to those who commit the sin of going bankrupt [8].

For the sake of brevity, our analysis of economic systems will nonetheless be arbitrarily limited to a consideration of the labour force. Stratified societies dominated by a strong political organization are often founded on forced labour systems [9]. However the coercion is structured-be it through slavery, serfdom or whatever, the emphasis is on political and social control rather than economic efficiency. Whatever is wasted (i.e. human labour) is considered expendable, and whenever a system considers its bottom strata expendable, its leaders are necessarily obliged to keep their followers as misinformed as possible.

In caste systems, work is performed by the members of all castes except the land owners. Actually, the land owners do a job of sorts: they decide the allocation of labour. Usually, the rule of thumb is that those lowest in the hierarchy do most of the work, and those highest do least. When it comes to distribution of the goods produced, the asymmetry remains but is, naturally, inverted [10]. Those low down get less; those high up get more. While it might seem unfair to sweaty labourers that the workers get the least out of the system, the priests justify distribution according to the worth of the people-inferior people get what they deserve, which is something less than what is received by superior people (meaning the priests and their elitist equals) [11]. Such a system is aided by the stupidity (i.e. jaded education) of people accepting their fate and acquiescing in their own exploitation, as slaves were encouraged to do in Christian, $19^{\text {th }}$ century America.

No matter what the system of labour organization, in agricultural communities, large families are advantageous in that there is always plenty of work to be done by extra hands. However, as a society industrializes, the large family becomes a liability [12] 
rather than an asset so a cultural conflict develops as traditional values are strained by new working conditions and challenged by a novel way of life. In such situations, stupidity is the big winner, with ignorance, poverty and despair following closely in about that order. More of these commodities are produced and distributed than can be imagined. Unlike the "Goods" of life, these "Bads" are doled out generously to those least in need of them. Seldom is the unstable base of such societies a serious concern to the leaders, who often repress threats of meaningful change.

If there is one constant across all civilizations, it is the unequal distribution of wealth. Increased productivity of advanced societies never promotes equitable prosperity as surpluses are drawn off to support those who organize most and produce least [13]. This inequality of wealth is so ubiquitous that the notion of economic equality must be one of those theoretical ideals which reformers find inapplicable to less than ideal humans. Some people invariably lord it over others, so as in the caste system mentioned above, people generally share goods but not equally: Those responsible for dividing up the goods invariably give themselves more than they allot to the producers. A prime example of this principle is provided by the colonial administrations of the early twentieth century which made a point of acquiring the best land, houses and social amenities of the subject countries for themselves [14]. All such systems, of course, are sanctified by priests, who are duly rewarded for their spiritual support of the morally bankrupt political establishment. This setup is unjust for the workers while it lasts and stupid for the priests and their cronies when it fails. There is little consolation for anyone in knowing that any failed system will be replaced as a new bunch of bandits replaces an old pack of thieves.

Along with poverty, another inescapable fact of civilization is collectivism. In most advanced societies, the large productive goodswaterworks, roads, equipment used in public services, factories, etc-are almost always collectively owned ${ }^{2}$ either by private groups (corporations) or governments [15]. Bigness is inescapable and means that civilization is characterized by collective stupidity. Gone are the good old days when an individual could just go off and fall flat on his very own face. More and more, stupidity is organized for people who can merely select for which fools they will work and with which knaves they will invest their time, energy and money. In the business world, the small entrepreneur, who tries to maximize profits in response to the specifics of his economic conditions, has been replaced by the corporation man, who seeks promotion by responding less to external events and more to a positive feedback system of rules, regulations and policies generated internally by the company [16]. In the political domain, government is there doing its worst to see to it that each of us has the same chance to accept and conform to PC standards set by the mediocracy. Further, as a tax payer, a person is working about $33 \%$ of the time not for himself but for the government-the least responsible institution ever to evolve.

There is much more than irony in the fact that so many people are so willing to work so hard in their own worst interest. Such behaviour is made all the more probable by the human capacity to believe in nonsense. People identify themselves so much with institutions, causes, ideologies and religions that they render themselves incapable of judging their own best or worst interests. It is sad enough if they believe that what is good for the system is good for them, but this belief tends to inhibit criticism. This gives leaders free rein to pursue their own self-aggrandizement. Labour unions provide some unfortunate examples of this phenomenon, as workers have eagerly lined up to be bamboozled by officials lavishly paid to price American workers out of the international labour market.

It would be nice to think that the allocation of material rewards would provide all who contribute to the production of goods at least minimal means for subsistence. In primitive societies, rights of access to water, food and shelter are assumed and honoured. A person can gather whatever is needed or wanted directly from nature and can share in the rewards of common efforts in rough proportion to his contribution to them. However, when existence depends on the ownership of land or on labouring for others, the issue of economic rights becomes both crucial and very arbitrary. Rights happen to be very circumstantial and incredibly alienable. Their existence is determined by people with a vested interest in seeing to it that workers get just enough to keep working. As we saw in Eastern Europe in the 1990's, rights turn out to be expressions of the numbers and organizational capacities of the disenfranchised and those sympathetic to their plight. Historically, in the case of the American labour movement, rights did not exist until workers brought them into being at the expense of owners' rights to control property. The waste to society of such conflicts of interest is the common alternative to oppression of one group by another. This, in turn, means that a certain amount of friction and inefficiency is characteristic of culture, although the form and intensity will vary from one to another. Intellectually, there is commonly a loss when, in addition, as Upton Sinclair observed, "It is difficult to get a man to understand something when his salary depends upon his not understanding it" [17].

\section{References}

1. Hammond P (1978) An introduction to cultural and social anthropology. ( $2^{\text {nd }}$ edn), Macmillan, New York, USA, p. 18.

2. Jones G (2016) Karl Marx: greatness and illusion. Harvard University Press, Cambridge, MA, USA, p. 139.

3. Ibid. p. 104.

4. Coolidge C (1973) Quoted in the glory and the dream by William Manchester. This was a trend begun or first recognized in France in the late $19^{\text {th }}$ century. (Zola, E Au Bonheur des Dames, 1883.) Little, Brown, Boston, MA, USA, p. 28.

5. Coolidge C (1965) Quoted in American heritage. XVI, p. 70.

6. Smith A. The theory of moral sentiments.

7. Galbraith J (1994) Quoted in USA today by mark memmott, 3B.

8. Mishra P (2017) Age of anger. Ferrar, Straus and Giroux; New York, USA, p. 96.

${ }^{2}$ Even in capitalistic systems, there is a often a significant degree of socialism-public ownership of essential utilities gas, electricity, etc-and transportation systems at the state and local levels. (Hayes A Generation of Materialism 212). 
9. Hammond. op. cit, p. 129.

10. Ibid. p. 246

11. Chamberlain N (1970) Beyond Malthus. A newscast in early 2018 stated that $1 \%$ of the population of the United States gained $82 \%$ of the wealth generated the previous year: $49 \%$ divided up the rest; $50 \%$ got nothing of it. Could this not be done more equitably? Basic Books; New York, USA, p. 16.

12. Hammond. op. cit. pp. 128-129.

13. Ibid. 56.

Creative Commons Attribution 4.0

International License

For possible submission use the below is the URL Submit Article
14. Thomson D (1962) Europe since napoleon. Longmans, London, UK, p. 805 .

15. Hammond. op. cit. p. 116.

16. Galbraith J (1981) A life in our times. Houghton Mifflin, Boston, MA, USA, pp. 350-351.

17. Sinclair U (2015) Undated quotation on p. 276 of Hodgkinson, T and Bergh, H. v. d. How to Sound Cultured. Publishers Group West; Berkeley, CA, USA. As an aside, socialist Sinclair was arrested on May 15, 1923, in LA for reading the Bill of Rights out loud. Pope J (Ed.), Strange Stories, Amazing Facts of America's Past, Reader's Digest, Pleasantville, NY, USA, p. 55.

\section{Your subsequent submission with Crimson Publishers}

\section{will attain the below benefits}

- High-level peer review and editorial services

- Freely accessible online immediately upon publication

- Authors retain the copyright to their work

- Licensing it under a Creative Commons license

- Visibility through different online platforms

- Global attainment for your research

- Article availability in different formats (Pdf, E-pub, Full Text)

- Endless customer service

- Reasonable Membership services

- Reprints availability upon request

- One step article tracking system 